\title{
NFKBIE wt Allele
}

National Cancer Institute

\section{Source}

National Cancer Institute. NFKBIE wt Allele. NCI Thesaurus. Code C52897.

Human NFKBIE wild type allele is located in the vicinity of 6 p21.1 and is approximately 8 $\mathrm{kb}$ in length. This allele, which encodes NF-kappa-B inhibitor epsilon protein, plays a role in the mediation of the cellular localization of the nuclear factor kappa B complex. 